\title{
The rare, giant gorgonian Ellisella paraplexauroides: demographics and conservation concerns
}

\author{
Manuel Maldonado ${ }^{1, *}$, María López-Acosta ${ }^{1}$, Luis Sánchez-Tocino ${ }^{2}$, \\ Cèlia Sitjà ${ }^{1}$ \\ ${ }^{1}$ Department of Marine Ecology, Centro de Estudios Avanzados de Blanes (CSIC-CEAB), Acceso Cala St. Francesc 14, \\ 17300 Blanes, Girona, Spain \\ ${ }^{2}$ Department of Zoology, Universidad de Granada, Campus Fuentenueva s/n, 18071 Granada, Spain
}

\begin{abstract}
A striking occurrence of the gorgonian coral Ellisella paraplexauroides off the Chafarinas Islands (western Mediterranean) requires serious conservation attention owing to considerable damage initiated by small fishing operations. Although this gorgonian is among the largest Atlantic-Mediterranean invertebrates, its biology remains virtually unknown. The studied population, established within an area of regulated fishing, was in unusually shallow waters $(12-32 \mathrm{~m})$. Density averaged 0.5 colonies $\mathrm{m}^{-2}\left(\max 5 \mathrm{~m}^{-2}\right)$; colony volume averaged $48 \mathrm{ml}(\mathrm{max}$ $511 \mathrm{ml})$, height averaged $76 \mathrm{~cm}(\max 167 \mathrm{~cm})$, and number of branches averaged $16(\max 72)$. Allometric growth revealed increasing branching and thickening once colonies reached approximately $60 \mathrm{~cm}$ in height. Size distribution suggested moderate to low recruitment. Three geographic zones of fishing pressure (A-C) were semi-quantitatively identified, based on the activity of a small-scale fishing fleet: 'A' had the highest level of fishing pressure (frequent gillnetting, trolling lines, and occasional trawling); ' $\mathrm{B}$ ' had the lowest level (occasional gillnetting and fishing lines), and ' $\mathrm{C}$ ' an intermediate level. Most fishing gear was tangled in the gorgonians in zones A and C. Mortality and colony damage were significantly higher in zones with intensive and poorly regulated fishing activity and appeared unrelated to predation or disease. In high-pressure zone A, about half $(44.6 \%)$ of the colonies were dead, while about $82 \%$ of the surviving colonies showed significant damage, with a large number of epibionts disrupting colony functioning. The Chafarinas population of $E$. paraplexauroides is likely a unique Mediterranean relic from a Mauritanian-Senegalese Pleistocene interglacial expansion but is now being seriously impacted by illegal fishing.
\end{abstract}

KEY WORDS: Gorgonian mortality $\cdot$ Population structure $\cdot$ Small-scale fishing $\cdot$ Fishing impacts · Gorgonian predation $\cdot$ Epibiosis $\cdot$ Chafarinas Islands $\cdot$ Corals

\section{INTRODUCTION}

The gorgonian Ellisella paraplexauroides (Stiasny 1936a) is one of the largest colonial invertebrates in the Mediterranean and the only member of the genus Ellisella (Anthozoa, Alcyonacea, Ellisellidae) recorded in European waters (Grasshoff 1992). In the North Atlantic, the species occurs along the west coast of Africa (from Angola to Morocco), off the Canary Is- lands, and at some sites in southwestern Spain (reviewed by Angiolillo et al. 2012). In contrast, E. paraplexauroides is rare and discontinuously distributed in the Mediterranean, thus far found only in isolated colonies on the Seco de los Olivos offshore bank (Almeria, Spain), around Alboran Island, along the Ceuta and Melilla coasts, at some locations off Algeria and Tunisia, and in the Strait of Sicily (Arroyo et al. 2008, Angiolillo et al. 2012). Samples are occasionally 
found in the catch of fishing trawls, and sightings have been reported during remotely operated vehicle (ROV) explorations (Oceana 2006, Angiolillo et al. 2012). The optimal depth range is believed to be 50 to $150 \mathrm{~m}$ (Arroyo et al. 2008, Angiolillo et al. 2012), although the species has been recorded at an extreme range of depths - from as deep as $690 \mathrm{~m}$ in the Canary Islands (Brito \& Ocaña 2004) to as shallow as 15 to $35 \mathrm{~m}$ in the vicinity of the Strait of Gibraltar and around the Chafarinas Islands (Arroyo et al. 2008). Although E. paraplexauroides is a large and charismatic invertebrate, very little is known about its basic ecology, biology, and population organization.

Our exploration of the deep continental shelf (70 to $200 \mathrm{~m}$ ) of Alboran Island via ROV in September 2011 and scuba dives on the shallow shelf (0 to $35 \mathrm{~m}$ ) of the Chafarinas Islands in September and October 2009 to 2011 revealed only a few scattered colonies of Ellisella paraplexauroides on the Alboran deep shelf, but a relatively dense population on the Chafarinas shallow shelf. This unusually shallow population resides primarily in a regulated fishing area on the archipelago shelf and provides an unparalleled opportunity to investigate the basic and thus far unknown demographic parameters of this species. To this end, we examined colony abundance, density, volume, biomass, size distributions, and 'health' condition. Colony health became particularly relevant, owing to the abundance of damaged and dead colonies observed during the period of study.

Some major threats to gorgonian populations are predation, disease, and fishing gear entanglement. Gastropods, crustaceans, and polychaetes are wellknown predators of gorgonian polyps (e.g. Ott \& Lewis 1972). Although predation rarely leads to colony death, a massive attack by caprellids has been shown to cause significant local mortality (e.g. Scinto et al. 2008). In the past decade, gorgonian populations have also reportedly suffered severe diseases triggered by a complex combination of pathogenic microbia and abnormally high seawater temperatures (Garzón-Ferreira \& Zea 1992, Nagelkerken et al. 1997, Cerrano et al. 2000, Perez et al. 2000, Rosenberg \& Ben-Haim 2002, Hall-Spencer et al. 2007, Coma et al. 2009). As just mentioned, the third major threat derives from assorted fishing practices, as is evident from increasing reports of damage in this regard. For instance, coastal sport fishing (fishing rods), artisanal small-scale fleets (operating longlining, trawling lines, gillnetting, trap deployment, etc.), and boat anchorage have been shown to damage from 25 to $40 \%$ of the gorgonians in areas where those activities are common (e.g. Bavestrello et al.
1997, Chiappone et al. 2005, Heifetz et al. 2009, Shester \& Micheli 2011). Therefore, we have also assessed the role of predation, disease, and small-scale fishing as sources of colony damage. As this study makes clear, the gorgonian populations off the Chafarinas Islands are being affected by illegal smallscale fishing within an area of regulated fishing.

\section{MATERIALS AND METHODS}

\section{Study region}

The Chafarinas Islands lie in the southern part of the Alboran Sea in the western Mediterranean (Fig. 1). This region has a complex hydrography, characterized by a large influx of North-Atlantic surface water, which in the Alboran Sea branches into several cyclonic and anticyclonic gyres (Tintoré et al. 1988, Vargas-Yáñez et al. 2002).

The archipelago of the Chafarinas Islands consists of 3 islets: Congreso, Isabel II, and El Rey, hereafter referred to as islands or zones $\mathrm{A}, \mathrm{B}$, and $\mathrm{C}$, respectively (Fig. 1). These islands are $3.2 \mathrm{~km}$ from the coast of Morocco, the closest land site. Islands A and C emit minimal pollution and sewage as they have been uninhabited for over 60 years. Since 1948, a small, but permanent, population-currently consisting of only about 40 members of the Spanish Army and 4 members of the Spanish Natural Parks (OAPN) - has been present on island B. The archipelago's terrestrial ecosystems have been protected under conservation legislation since 1982, whereas the marine habitats received little attention until July 2006, when the islands gained the legal status of a Site of Community Importance (SCI). As a result, fishing and extractive activities have come under regulation within a band of water extending $0.5 \mathrm{~km}$ from the archipelago coastline. Nevertheless, both before and after the declaration of SCI status, Spanish authorities have done little to discourage the illegal trawling and gill-net fishing that local fishermen conduct daily within the SCI regulated zone. In 2 of the selected study zones, that is, on the western side of island A and the eastern side of island C (Fig. 1), poaching is particularly prevalent because illegal fishers can go undetected. Since the Spanish authorities staff the watchtowers only on island B, poaching seldom occurs in the third study zone on the northern side of island B (Fig. 1), which is located directly below the main watchtower.

Because bottom trawling, gillnetting, and/or trolling are known to have a considerable impact on 


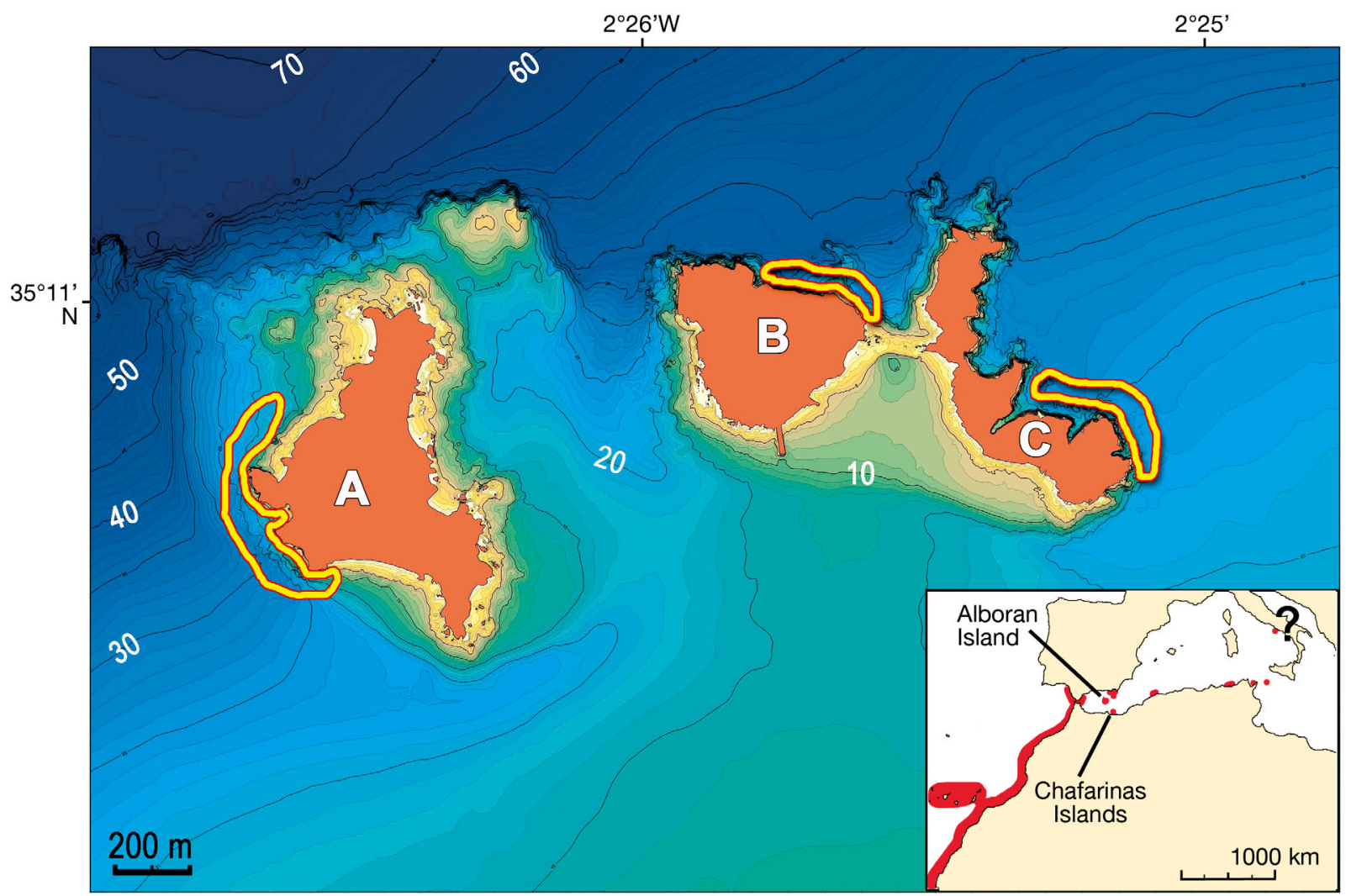

Fig. 1. Biogeographical distribution of Ellisella paraplexauroides. The inset shows the general species distribution (in red) relative to the Alboran and the Chafarinas Islands; the occurrence of the species in coastal waters around Naples is doubtful (?). The larger map shows the specific location of the 3 study zones (outlined in yellow) around the Chafarinas Islands $(\mathrm{A}=$ Congreso island, B = Isabel II island, C = El Rey island); white numbers = bottom isobaths

large 3-dimensional organisms such as Ellisella paraplexauroides, it seemed useful to compare the results of fishing pressure in these 3 zones. During our scuba dives, we documented evidence of fishing lines and gillnet gear on the bottom of all 3 zones, which coincides with available OAPN information. Fishing gear was more abundant in zone A than in zones B and C. In zone A, we photographed cases of illegal trawling occurring less than $150 \mathrm{~m}$ from the island shore and in depths of about 10 to $15 \mathrm{~m}$. In recent years, OAPN staff have documented similar illegal trawling both in zone A and in zone C. Still cameras have captured evidence of gill net deployment in these 2 zones as well, although the authorities have seized such nets in only a single case in the past 4 years. It was difficult to quantify the exact between-zone differences in fishing pressure as many of the gear deployments occur during the night and monitoring these activities was risky and beyond the logistical capabilities of the research team. Even so, all information collected to date makes it clear that fishing pressure in zone $\mathrm{A}$ is higher than in zone $\mathrm{C}$, which in turn is higher than in zone B.

The various environmental parameters (e.g. seawater temperature, salinity, plankton abundance, siltation, overall hydrodynamic exposure) in the 3 study zones exhibit no major differences that could substantially affect gorgonian occurrence (Fig. 1). Indeed, colonies of Ellisella paraplexauroides and several other gorgonians are common in all 3 zones. Bottom structure is also similar in the 3 study zones: from 0 to $20-25 \mathrm{~m}$, vertical rocky walls and overhangs alternate with a less steep hard-bottom profile (Fig. 1); below 20 to $25 \mathrm{~m}$, the bottom consists of a sandy seabed with a scattering of large boulders.

\section{Sampling design}

Our team made 3 fortnightly trips to the Chafarinas Islands, the first of which occurred in October 2009 and focused on inspecting the population, identifying potential sources of damage, and establishing an ap- 

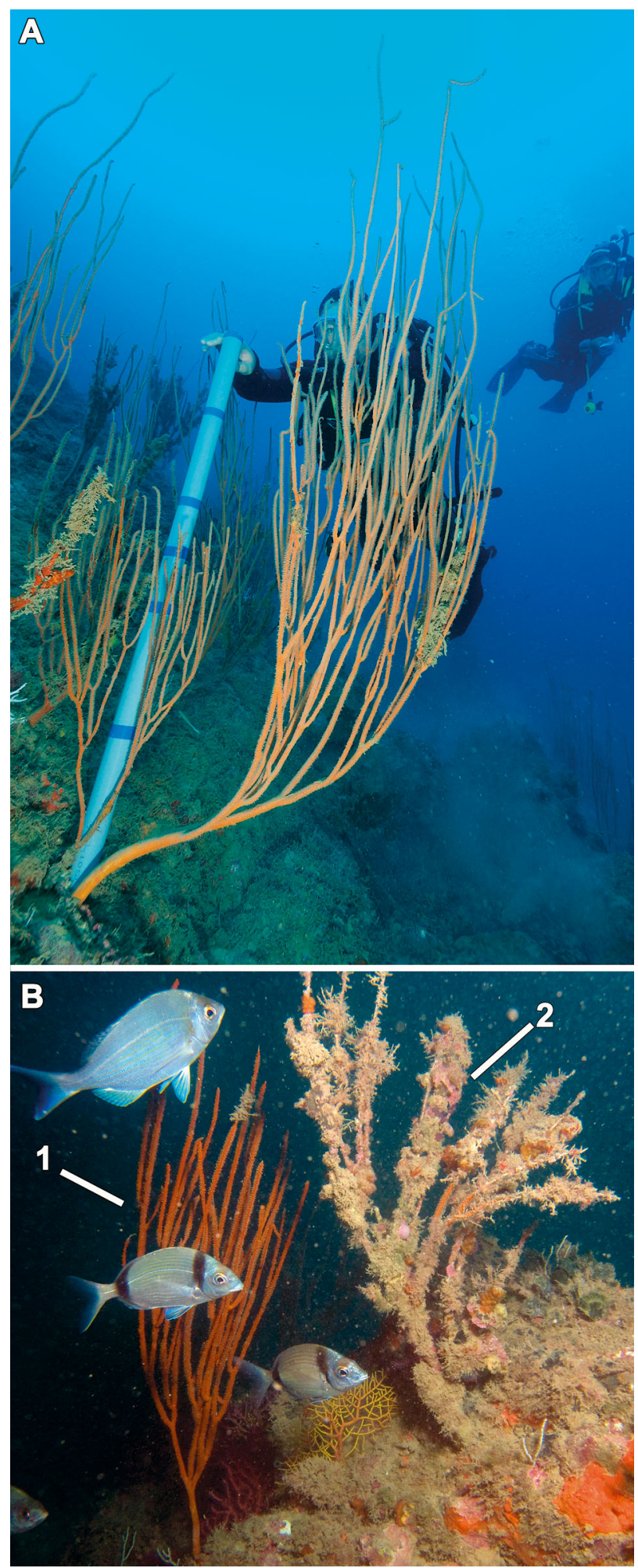

Fig. 2. Ellisella paraplexauroides. In situ views of the gorgonian at 15-32 m depth. (A) Healthy colonies at $25 \mathrm{~m}$ in zone $\mathrm{B}$, being photographically scaled with the help of a marked $1 \mathrm{~m}$ pole for further morphometric analyses. (B) Comparative view of a healthy colony (1) adjacent to a dead colony (2) entirely fouled by epibionts proach to survey design. The 2 subsequent trips (in October 2010 and September 2011) were devoted to the survey and data collection. Colony abundance, size, damage, and mortality counts were obtained using $1 \times 1 \mathrm{~m}$ quadrats during scuba dives. The quadrat size was 4 times larger than that usually applied in work on midsized gorgonians, such as Paramuricea clavata (e.g. Linares et al. 2008). It was also the largest practicable size with which to achieve high survey replication as well as meet dive safety standards. The quadrats were randomly distributed at depths of 12 to $32 \mathrm{~m}$, and the number of living and dead gorgonians recorded in each. We also obtained wide-angle, scaled digital images of each gorgonian (Fig. 2). Photographs were processed using Image J Software to quantify volume, biomass, total height, number of terminal branches (tips), and epibiont load (see details in subsequent sections). Living gorgonians were divided into 2 categories: healthy (with no noticeable physical damage or epibiotic load; Fig. 2A) and damaged (showing obvious physical injuries, fishing line tangles, and/or serious epibiotic load; Fig. 2B). We took high numbers of replicates in the quadrats of all 3 zones $\left(\mathrm{n}_{\mathrm{A}}=250 ; \mathrm{n}_{\mathrm{B}}=252 ; \mathrm{n}_{\mathrm{C}}=\right.$ 258) to ensure that representative values could be obtained for each of the quantifiable variables.

\section{Density of colonies}

Average $( \pm \mathrm{SD})$ number of living colonies $\mathrm{m}^{-2}$ were estimated for each study zone (A, B, C) and then pooled for the entire archipelago. Because the most suitable conditions for Ellisella paraplexauroides growth are assumed to be in the 50-150 depth range whereas we were investigating an unusually shallow population $(<35 \mathrm{~m}$ depth), we had to consider the possibility that the Chafarinas population might consist of highly stressed colonies growing at the upper limit of their environmental tolerance. To test this plausible hypothesis, we examined the density of colonies for variation with depth over the range of sampled depths (12 to $32 \mathrm{~m}$ ) using regression analysis.

\section{Biomass, size and morphological complexity}

Morphometric software applied to the scaled digital images (Fig. 2A) provided estimates of total volume, maximum height, and number of terminal branches (tips) for each colony. The tip data served to indicate actual branching level or morphological complexity. 
To estimate volume, we decomposed the 2-dimensional images of the gorgonian colonies into a collection of geometric figures (cone, truncated cone, and cylinder). Length, diameter, and area were measured for each geometric figure and volume calculated from these data. Because Ellisella paraplexauroides is a large coral and images of colonies can best be obtained with a wide-angle lens and low aperture setting, all branches that appear in an image are not in the same plane as in the coral's natural state. Nor are all branches perfectly orthogonal to the plane of the image because of camera-setting restrictions. These small deviations from the true state of the coral in situ need to be considered when reconstructing volume from images. To determine the magnitude of any such error, we took images of 8 sections of the gorgonian colonies, then sampled pieces of the photographed colony and determined their volume (ml) by water displacement. The more accurate volumedisplacement values were then compared with those estimated from the image analysis. A paired $t$-test indicated that the photographic method ( $\mathrm{df}=7, t=$ 6.313, $\mathrm{p}<0.001)$ tended to slightly overestimate volume compared with the displacement method (20.1 $\pm 4.9 \%)$. Volume data from photographic images were then corrected by multiplying by a factor of 0.79 . Collected samples of known volume were then dried at $60^{\circ} \mathrm{C}$ to constant dry weight (DW) and were used to infer the relationship between volume (ml) and DW (g) via regression analysis. This procedure allowed an inferred biomass (as DW g) to be estimated from volume and thus avoided any further destructive morphometric approach to the gorgonian colonies.

In our morphometric assessment, we also calculated the frequency distribution for volume, biomass, height, and number-of-tips classes in each zone and in the overall combined population, and investigated whether the results fit known distribution models. To assess frequency distributions, we rearranged volume data into $20-\mathrm{ml}$ classes, height into $10-\mathrm{cm}$ classes, and number of tips into 5-branch classes. This produced a similar number of classes for all the study variables. Finally, regression analysis was used to evaluate allometry between volume, height, and branching.

\section{Epibiosis, damage and mortality}

During the initial inspection dives in 2009, a surprisingly high number of colonies (hereafter referred to as fouled colonies) were observed serving as sub- strate for a large variety of epibionts (Fig. 2B). This led us to consider whether this epibiotic load might be substantial because the gorgonian population was living in shallow water at the upper bathymetric limit of its environmental tolerance. That is to say, the Chafarinas population could consist of highly stressed colonies that would be unable to protect their surface against epibiont settlement. We tested this hypothesis in 2 ways. First, the incidence of epibiosis $\mathrm{m}^{-2}$ was quantified as the number of gorgonians affected by epibiosis in a quadrat relative (\%) to the total of living colonies in that particular quadrat. Empty quadrats and quadrats with only dead colonies were excluded from the analyses. Under the hypothesis that epibiosis might be related largely to a colony's occurrence at the upper bathymetric limit, one could expect the incidence of epibiosis to decrease with increasing depth.

Initial inspection dives also revealed that many of the gorgonians had fishing lines and pieces of net material tangled in their branches; they had broken branches, scars from surface abrasion, and some polyps removed-all of which suggested contact with fishing gear. Therefore, it appeared that the large epibiotic loads could be related not only to a potential shallow-water effect but also to recurring damage that fishing gear inflicts on colony skeletons, the coenosarc, and polyps. In this case, epibiosis incidence per $\mathrm{m}^{2}$ and epibiotic load per colony should be greater in zone A (where the highest fishing pressure occurs from trawling, netting, and trolling lines) than in zone $\mathrm{C}$ (an area where netting and trolling are more prevalent), which in turn should be higher than in zone B (where no trawling occurs, netting is occasional, and trolling is a common practice).

Visual inspection during scuba dives also revealed a relatively high number of dead and dying gorgonians in some zones, as indicated by remnants of colony stems and colonies with $>90 \%$ of their surface covered by epibionts. The incidence of mortality $\mathrm{m}^{-2}$ was quantified by calculating the proportion (\%) of dead colonies in a quadrat in relation to the total number of colonies occurring in that particular quadrat. This measure was applied only in quadrats containing only dead or living colonies, or a combination of both $(n=615)$. To explore whether disease and predation were significant causes of mortality in this gorgonian population, counts were made of the number of colonies showing evidence of disease and the number bearing potential predators. However, counts turned out to be insignificant in both cases, so no further analyses of this kind were carried out. 


\section{Statistical analyses}

To ascertain whether between-zone difference in fishing pressure had an effect on the average density, volume, biomass, height, number of tips, epibiosis incidence (\%), epibiosis load, and incidence of mortality $(\%)$, the non-parametric Kruskal-Wallis test was applied on untransformed, non-normally distributed data. A posteriori pairwise comparisons to identify which zones were responsible for the significant differences were made using the non-parametric Dunn's method. Sample sizes for analyses of volume, biomass, height, and number of tips were $\mathrm{n}_{\mathrm{A}}=62, \mathrm{n}_{\mathrm{B}}=188$, and $\mathrm{n}_{\mathrm{C}}=195$. Sample sizes for epibiosis incidence (\%) were $\mathrm{n}_{\mathrm{A}}=38, \mathrm{n}_{\mathrm{B}}=112$, and $\mathrm{n}_{\mathrm{C}}=112$, and for mortality incidence $(\%), \mathrm{n}_{\mathrm{A}}=51, \mathrm{n}_{\mathrm{B}}=120$, and $\mathrm{n}_{\mathrm{C}}=135$.

Allometry between volume, height, and branching was investigated using regression analysis to examine the pairwise relationships between these parameters for each zone $\left(\mathrm{n}_{\mathrm{A}}=62, \mathrm{n}_{\mathrm{B}}=188, \mathrm{n}_{\mathrm{C}}=195\right)$, as well as for all zones combined $(\mathrm{n}=445)$.

Bathymetric patterns in density of colonies, volume, biomass, height, tip number, epibiotic load, incidence of epibiosis (\%) and incidence of mortality (\%) within each zone and collectively for the total number of sampled quadrats were investigated through regression model fitting. For the analyses of volume, biomass, height, number of tips, and epibiotic load data sets, the sample sizes were $\mathrm{n}_{\mathrm{A}}=62$, $\mathrm{n}_{\mathrm{B}}=188$, and $\mathrm{n}_{\mathrm{C}}=195$. For incidence of epibiosis, sample sizes were $\mathrm{n}_{\mathrm{A}}=38, \mathrm{n}_{\mathrm{B}}=112$, and $\mathrm{n}_{\mathrm{C}}=112$, and for incidence of mortality, they were $n_{A}=51$, $\mathrm{n}_{\mathrm{B}}=120$, and $\mathrm{n}_{\mathrm{C}}=135$.

\section{RESULTS}

\section{Density of colonies}

A total of 445 living organisms were recorded in the 760 sampling quadrats, averaging a density of $0.59 \pm 0.99$ colonies $\mathrm{m}^{-2}$, with a maximum of 5 gorgonians $\mathrm{m}^{-2}$. Average density in zone A $(0.25 \pm 0.67$ colonies $\mathrm{m}^{-2}$ ) was significantly lower than that in zones $\mathrm{B}$ and $\mathrm{C}(0.75 \pm 1.03$ and $0.76 \pm 1.12$, respectively), which were not statistically different from each other (Fig. 3A). In the bathymetric range covered in this study $(12-32 \mathrm{~m})$, the density of living colonies did not correlate with depth either when all samples were pooled (Fig. 3B) or when each zone was analyzed separately (data not shown).

It is also noteworthy that at the $1 \mathrm{~m}^{2}$ scale used for sampling, the colonies were not uniformly distrib-
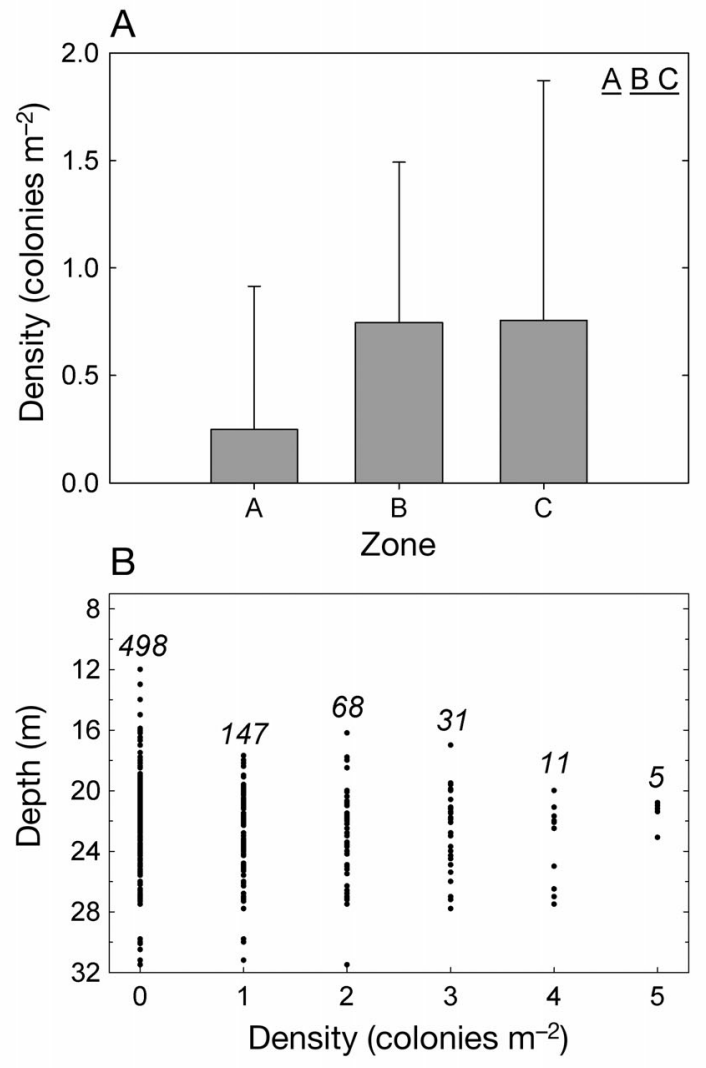

Fig. 3. Ellisella paraplexauroides. (A) Summary of statistically significant differences in density average $( \pm \mathrm{SD})$ as a function of study zone (A, B, C) following a Kruskal-Wallis test $(H=58.66$, $\mathrm{df}=2, \mathrm{p}<0.001)$ and a posteriori pairwise Dunn's tests. Letters in the upper right corner indicate study zones ordered by increasing value in colony density, with zones that are not significantly different from each other sharing underline. (B) Colony density in each $1 \times 1 \mathrm{~m}$ quadrat plotted versus the depth at which each quadrat was located. There is no substantial association $\left(\mathrm{r}^{2}=0.006, \mathrm{p}=\right.$ $0.03, \mathrm{n}=760$ ) between both variables. Numbers in italics indicate number of sampled quadrats

uted within the overall population (Fig. 3B). Rather, a large number of quadrats were empty, and most that were occupied contained only 1 or 2 colonies. This pattern is largely a reflection of the patchiness of hard substrate suitable for gorgonian settlement, intermingled with unfavorable soft substrate. Five quadrats had a maximum occurrence of 5 living colonies.

\section{Biomass, size and morphological complexity}

Colony volume within the population averaged $48.25 \pm 54.60 \mathrm{ml}$, with the largest colony $(511.39 \mathrm{ml})$ being about 10 times that of the average volume. Colony biomass (as DW g) was directly related to 

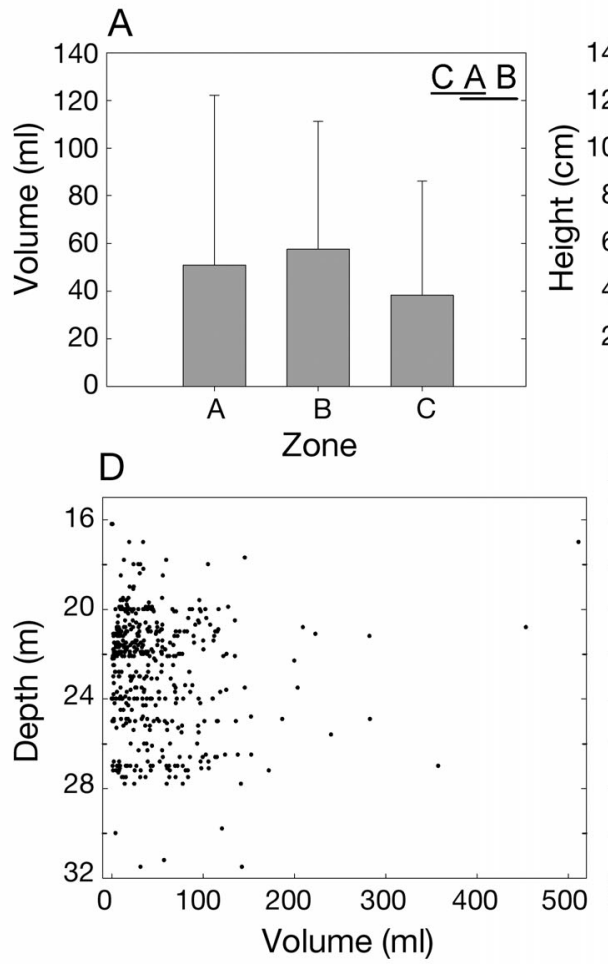
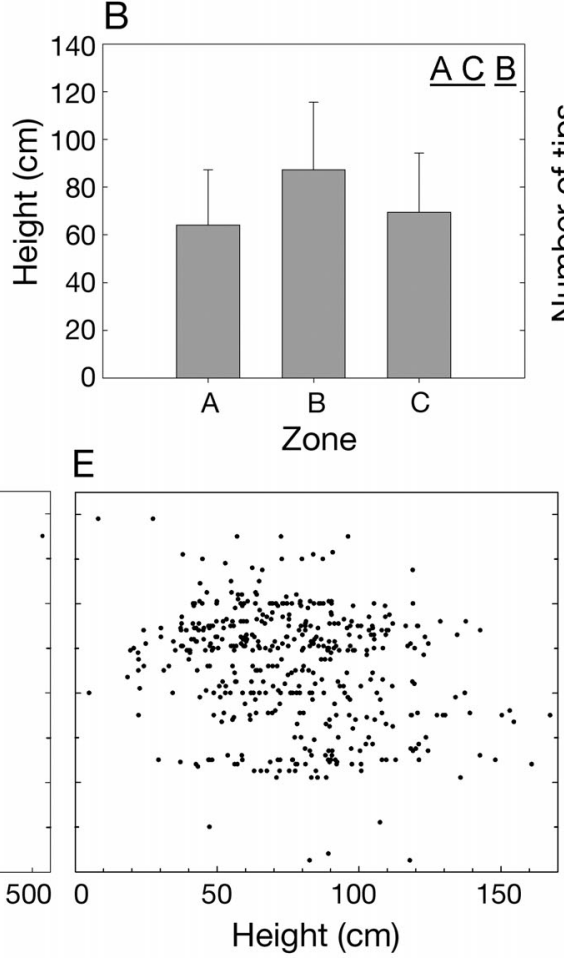
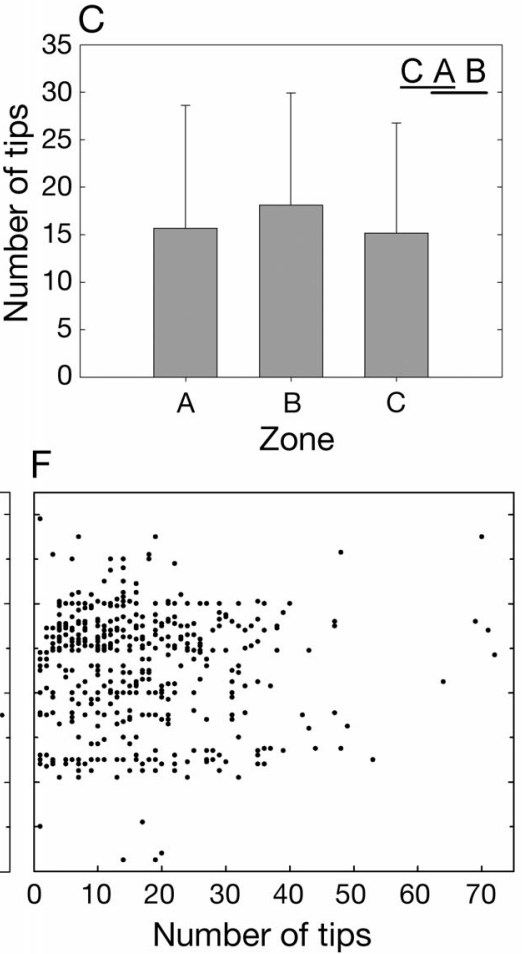

Fig. 4. Ellisella paraplexauroides. Summary of statistically significant differences in average $( \pm$ SD) $(A)$ volume, (B) height, and (C) number of tips, as a function of study zone, following in all cases a significant Kruskal-Wallis test $(\mathrm{df}=2,0.001<\mathrm{p}<0.01)$ and a posteriori pairwise Dunn's tests. Letters in the upper right corner indicate study zones ordered by increasing value in average volume, height, or number of tips, with zones that are not significantly different from each other sharing underline. Also shown are data on (D) volume, $(E)$ max height, and $(F)$ number of tips of each sampled colony $(n=445)$ plotted versus the depth at which colonies occurred. There is no statistically significant bathymetric pattern for these variables

volume $(\mathrm{ml})$, as shown by a linear equation ( $\mathrm{DW}=$ $-0.763+1.574 \times$ volume; $\left.\mathrm{n}=8, \mathrm{r}^{2}=0.947, \mathrm{p}<0.001\right)$. Because of this direct relationship between both biomass and volume variables, their distribution patterns across zones and by depth levels are always identical. Consequently, analytical results are only shown for the measured variable, i.e. volume. Height averaged $76.32 \pm 27.74 \mathrm{~cm}$, with the tallest colony being $167 \mathrm{~cm}$. Number of terminal branches (tips) averaged $16.50 \pm 11.94$, with the most branched colony displaying 72 tips (Table S1 in the Supplement at www.int-res.com/articles/suppl/m479p127_ supp.pdf).

Between-zone differences in volume (Fig. 4A), biomass (Table S1 in the Supplement), and number of tips (Fig. 4C) showed similar patterns. Gorgonians in zone B were significantly larger in volume (57.69 \pm $53.44 \mathrm{ml})$ and more branched (18.12 \pm 11.84 tips) than those in zone $\mathrm{C}(38.32 \pm 47.79 \mathrm{ml} ; 15.18 \pm 11.58$ tips $)$. Gorgonians in zone A were characterized by intermediate values of volume and number of tips, with Dunn's test not recognizing these A values as significantly different from those in B or C (Fig. 4A,C). Colony height showed a slightly different pattern, with average height in zone $\mathrm{B}$ being significantly larger $(87.32 \pm 28.29 \mathrm{~cm})$ than that in zones $\mathrm{C}$ and $\mathrm{A}$ $(69.60 \pm 24.73$ and $64.13 \pm 23.14 \mathrm{~cm}$, respectively). Zones $\mathrm{A}$ and $\mathrm{C}$ were not statistically different from each other (Fig. 4B).

Volume, height, and number of tips did not correlate with depth, neither when the analyses were run separately for each zone (data not shown) nor when all samples were pooled (Fig. 4D-F).

When the morphometric variables (volume, height, and number of tips) were analyzed in terms of frequency distribution ( $f$ ), each fitted a different distribution model (Fig. 5). Only the results at the population level (i.e. the 3 study zones pooled) are presented here, as distribution trends did not change when zones were analyzed separately. Volume (and biomass) significantly conformed with an exponential decay distribution (Fig. 5A). The most frequent volume class consisted of colonies smaller than $20 \mathrm{ml}$. In contrast, colony height better fitted a relatively symmetric Gaussian distribution (Fig. 5B). The most frequent colony height ranged from 80 to $90 \mathrm{~cm}$, but classes from 40 to $80 \mathrm{~cm}$ were also well represented. From the frequency distribution of volume and 

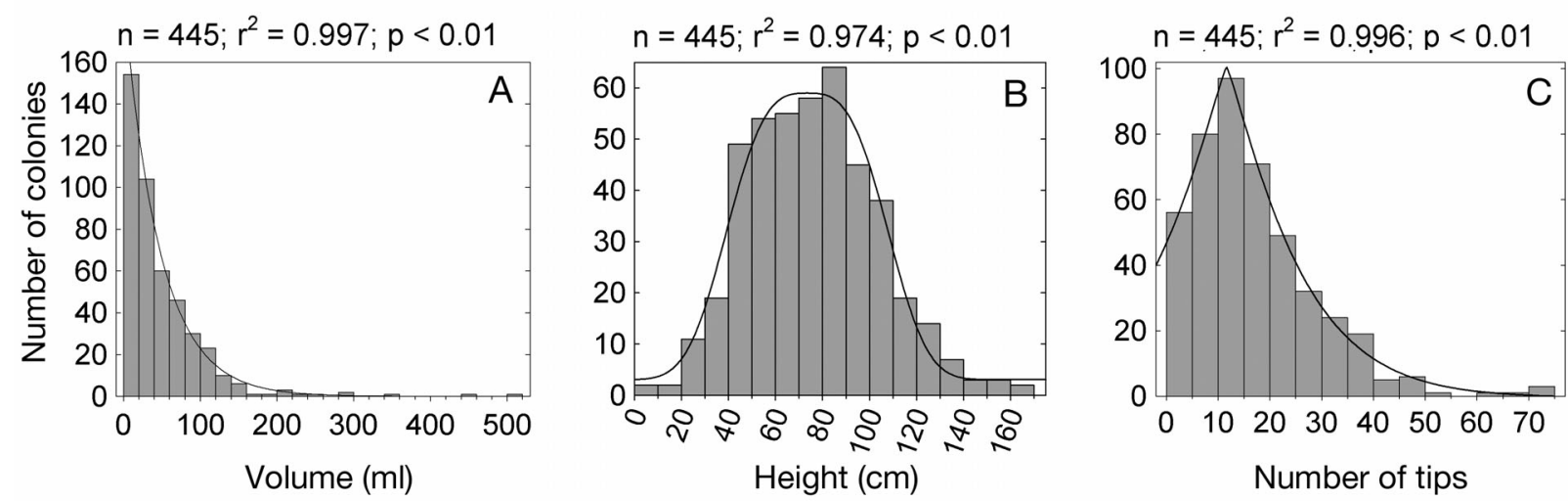

Fig. 5. Ellisella paraplexauroides. Frequency distributions $(f)$ of colony (A) volume, (B) maximum height, and (C) number of tips. Volume distribution significantly fits an exponential decay function $\left(f=191.15 \times \mathrm{e}^{-0.02 \times \text { volume }}\right)$. Height distribution fits a symmetrical Gaussian function $\left(f=3.06+55.91 \times \mathrm{e}^{-0.5 \times\left[\frac{h \text { hight }-73.55}{31.46}\right]^{3.12}}\right)$. Number of tips better fits a modified Gaussian function $\left(f=-0.46+101.10 \times \mathrm{e}^{-0.5 \times\left[\frac{\text { notips }-11.64}{8.06}\right]^{1.16}}\right)$. Statistics for fitting significance are given above each graph

height data, it can be deduced that only a moderate number of young, small colonies are recruiting into the population (see 'Discussion'). The number of tips conformed to an asymmetrical Gaussian distribution (Fig. 5C), with the most frequent class consisting of colonies characterized by 10 to 15 terminal branches.

Morphometric analyses revealed that height increased with both volume and number of tips, following an exponential rise to a maximum (Fig. 6). This pattern largely coincides with that of a hyperbolic function, which showed only a slightly inferior level of fit. The mathematical relationship suggests that initially young colonies grow faster in height than in total volume and number of branches; it appears that once the colony reaches a threshold height (between 60 and $100 \mathrm{~cm}$ ), that aspect of growth slows down, and the production of new branches, and branch thickening, accelerates.

\section{Epibiosis and damage}

A total of $302(67.8 \%)$ of the 445 colonies examined showed some epibiotic load. In addition, most (77.4\%) of the fouled colonies exhibited some signs of physical damage (e.g. broken branches, surface erosion and
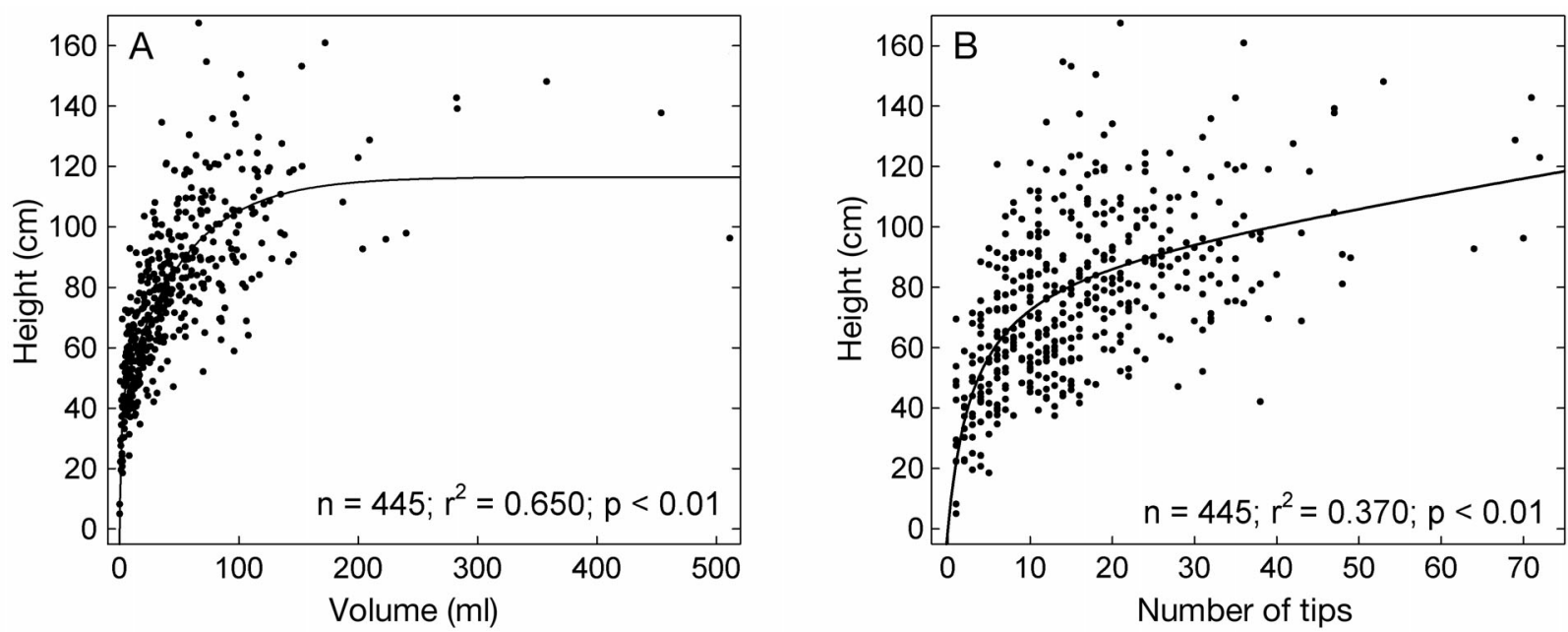

Fig. 6. Ellisella paraplexauroides. Allometry of colonies. (A) Relationship between colony volume and maximum height, significantly fitting an asymptotic exponential regression (height $=41.83 \times\left(1-\mathrm{e}^{-0.65 \times \text { volume }}\right)+74.66 \times\left(1-\mathrm{e}^{-0.02 \times \text { volume }}\right)$ ). $($ B) Relationship between number of tips and maximum height, also fitting an asymptotic exponential regression function (height $\left.=56.49 \times\left(1-\mathrm{e}^{-0.44 \times \text { no tips }}\right)+65.07 \times\left(1-\mathrm{e}^{-0.03 \times \text { no tips }}\right)\right)$. Statistics for fitting significance are given at the bottom of each graph 

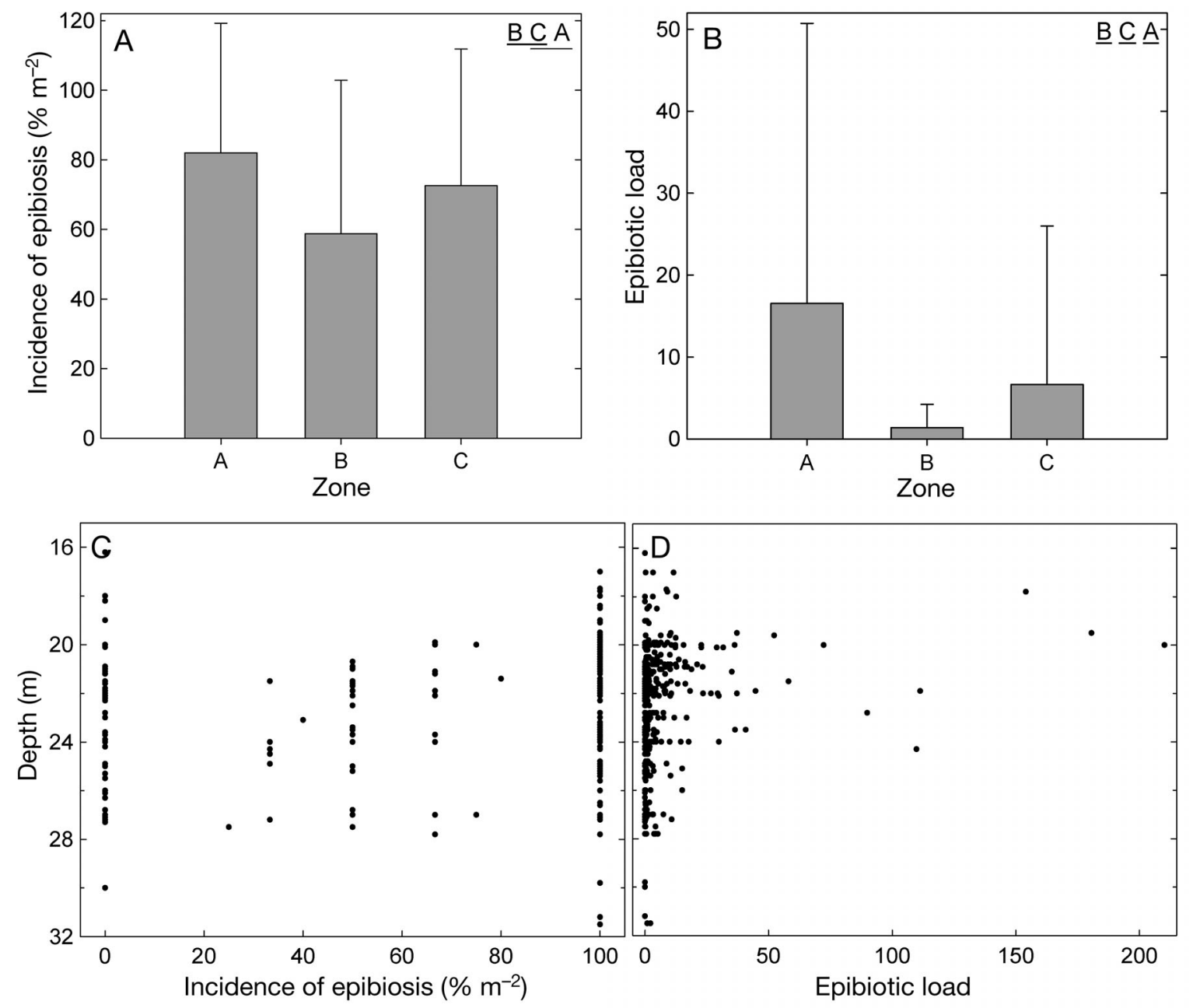

Fig. 7. Epibiosis on Ellisella paraplexauroides. (A) Summary of between-zone differences in incidence of epibiosis (i.e. \% of fouled colonies $\mathrm{m}^{-2}$ ) and (B) epibiotic load per colony (epibiont volume relative to gorgonian volume), as indicated by significant Kruskal-Wallis tests $(\mathrm{df}=2, \mathrm{p}<0.005)$ followed by pairwise a posteriori tests. Letters in the upper right corner indicate study zones ordered by increasing value in incidence of epibiosis or epibiotic load, with zones that are not significantly different from each other sharing underline. Data on incidence of (C) epibiosis and (D) epibiotic load plotted versus the depth at which each quadrat (for C) or colony (for D) was located. No statistically significant bathymetric pattern was recognizable for these epibiosis parameters

healing scars). The incidence of epibiosis in the population (i.e. \% of fouled colonies $\mathrm{m}^{-2}$ ) averaged $68.05 \pm$ $41.86 \%$. Epibiotic load per colony (i.e. total volume of epibionts relative to the gorgonian volume) averaged $5.80 \pm 18.77$, which means that the volume of epibionts was on average 5 times that of the gorgonians. Epibiotic load on Ellisella paraplexauroides typically consists of macroalgae, sponges, other cnidarians, bryozoans, and tunicates, as well as a large variety of other organisms in lower abundance (Fig. 2B).

When the incidence of epibiosis was analyzed as a function of zone (Fig. 7A), the percentage of fouled colonies in quadrats of zone A (which had the highest fishing pressure) was significantly higher than in zone B (which had lowest fishing pressure). Zone C (with intermediate levels of fishing pressure) showed intermediate values, which Dunn's tests failed to recognize as significantly different from those in A or B (Fig. 7A). The analysis of the epibiotic load revealed a similar pattern, but in a more powerful way. Colonies of zone A displayed an epibiotic load significantly higher than those in zone $\mathrm{C}$, which in turn showed a larger load than those in zone B (Fig. 7B).

Interestingly, unlike zone, depth showed no significant effect on either epibiosis incidence or epibiont load per colony. High and low values of epibiosis occurred at all depths within the investigated bathymetric range (Fig. $7 \mathrm{C}, \mathrm{D}$ ). 

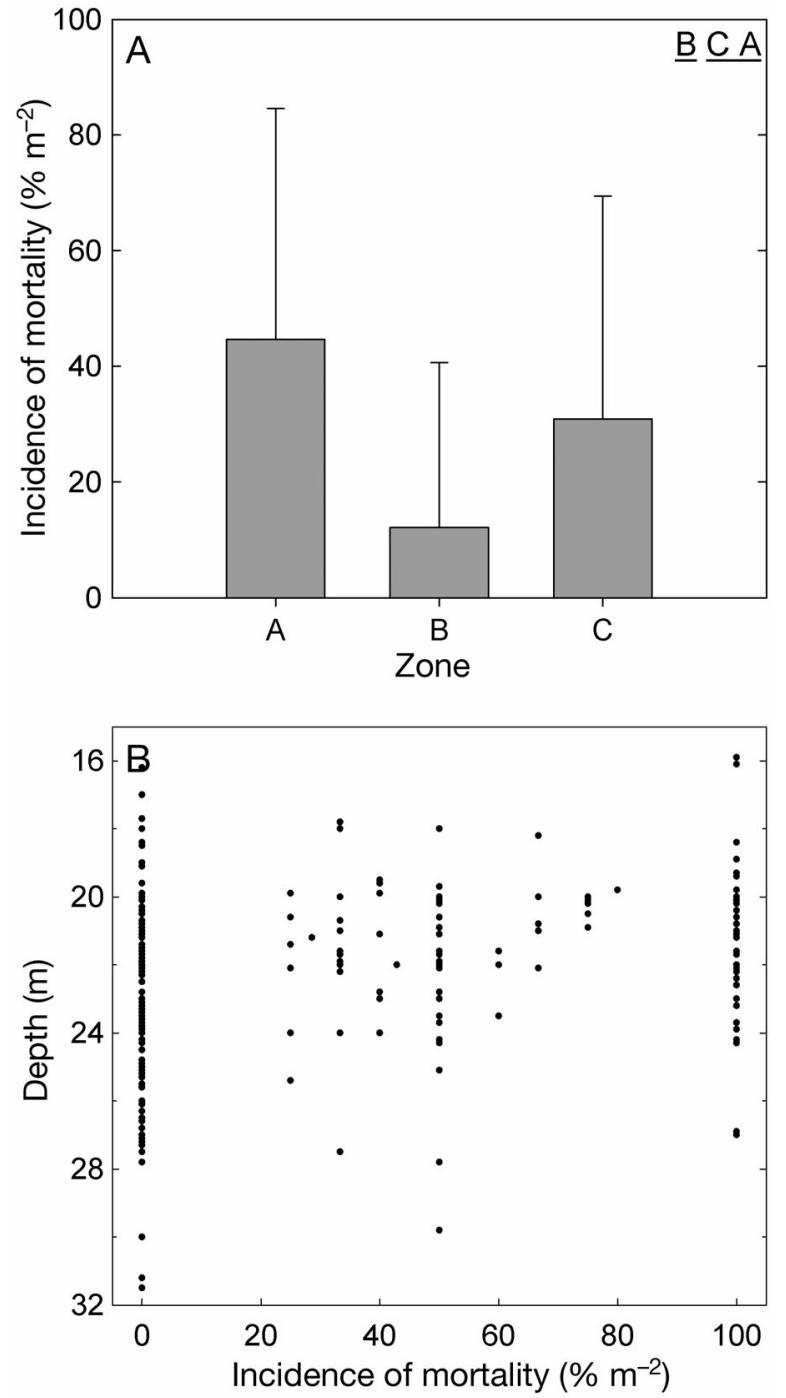

Fig. 8. Ellisella paraplexauroides. (A) Between-zone differences in incidence of mortality $\mathrm{m}^{-2}\left(\%\right.$ of dead colonies $\left.\mathrm{m}^{-2}\right)$, as indicated by a significant Kruskal-Wallis test $(H=36.82$, $\mathrm{df}=2$, $\mathrm{p}<0.001$ ) followed by pairwise a posteriori tests. Letters in the upper right corner indicate study zones ordered by increasing value in mortality incidence, with zones that are not significantly different from each other sharing underline. (B) Incidence of mortality plotted versus depth, showing no statistically recognizable relationship between both variables

\section{Mortality}

A total of 170 dead colonies occurred in the 760 sampled quadrats, averaging $0.22 \pm 0.63$ dead colonies $\mathrm{m}^{-2}$. Because the density of dead gorgonians can only be properly assessed if compared to the density of living colonies, we also examined the proportion (\%) of dead colonies in a quadrat relative to the total (dead + alive) number of colonies occurring in that same quadrat (i.e. incidence of mortality). Calculated in this way, the incidence of mortality averaged 25.83 $\pm 37.08 \%$ at the population level. However, this parameter was not uniformly distributed across zones. The Kruskal-Wallis tests and a posteriori comparisons revealed that incidence of mortality in zone B $(12.15 \pm 28.48 \%)$ was significantly lower than in zones $\mathrm{A}$ and $\mathrm{C}(44.66 \pm 39.90$ and $30.87 \pm 38.55 \%$, respectively), which were not statistically different from each other (Fig. 8A). In other words, in zones $\mathrm{A}$ and $\mathrm{C}$, where fishing pressure was high to medium, a dead colony occurred for about every 1 or 2 living colonies. In contrast, in zone B a dead colony occurred for every 9 living ones. Note that mortality incidence did not correlate with depth at the population level (Fig. 8B) or at the zone level. These results strongly suggest that most mortality in the Chafarinas population resulted from unregulated fishing (trawling, gillnetting, and trolling; Fig. 9) rather than from the unusually shallow depths inhabited by the colonies.

During the 3 year study, we found no epidemic disease affecting the gorgonian populations of the Chafarinas Islands; i.e. neither affecting Ellisella paraplexauroides nor other common species (e.g. Eunicella spp., Leptogorgia spp., Paramuricea clavata). Predation did not appear to be a significant mortality factor either. Although we noticed large individuals (30 to about $60 \mathrm{~cm}$ ) of the bearded fireworm Hermodice carunculata (Pallas, 1766) feeding on E. paraplexauroides (Fig. 10A,B), polychaete predation was restricted to the polyps at branch tips (Fig. 10C), thus causing only small terminal injuries that underwent rapid recovery with no significant adverse effect on the colony (Fig. 10D,E).

\section{DISCUSSION}

\section{Abundance and distribution}

Ellisella paraplexauroides is an Atlantic-Mediterranean gorgonian rarely found in the Mediterranean (Templado et al. 2006, Arroyo et al. 2008). For this reason, the occurrence of a relatively profuse population off the Chafarinas Islands (averaging a colony every $2 \mathrm{~m}^{2}$ ) is somewhat puzzling. Because the basic ecological information on this species is still poor, it is difficult to arrive at demographic comparisons with other species. The most common Atlantic-Mediterranean gorgonian species are smaller in height and colony diameter, and therefore their spatial distribution may obey different constraints regarding competition for food and space, reproductive output, etc. 

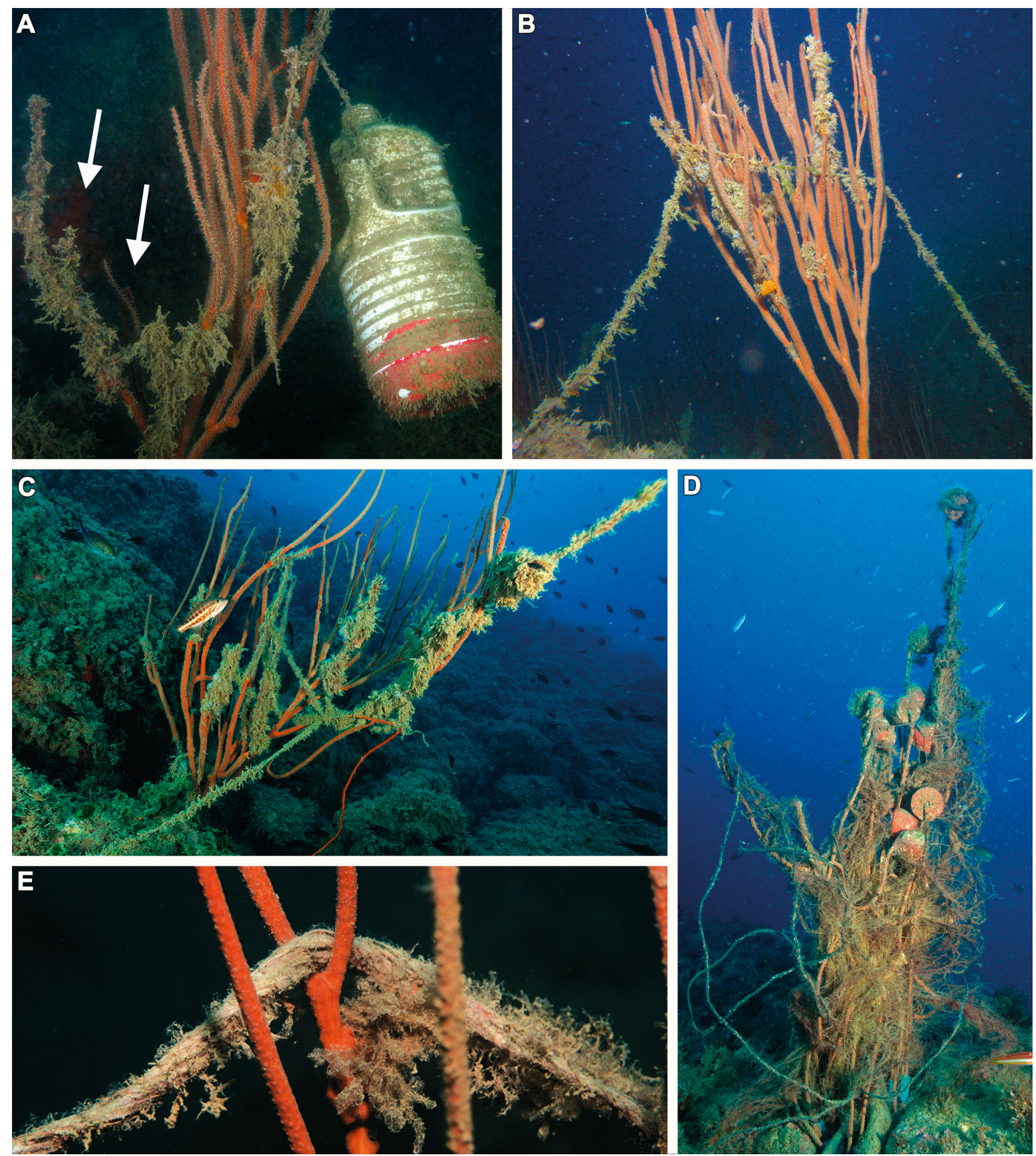

Fig. 9. Ellisella paraplexauroides. Damage of colonies by fishing gear. (A) Example of damaged colony, with a plastic bottle (used by local fishermen as a buoy for marking deployed guillnets) tangled in the branches, several missing branches (white arrows), and a significant load of epibionts. (B,C) Additional examples of colonies with tangles of lines used for gillnetting and trolling, and displaying substantial epibiont loads. (D) Colony killed after massive tangle of a gillnet. (E) Detail of a fish line eroding the colony coenosarc and favoring epibiont settling 

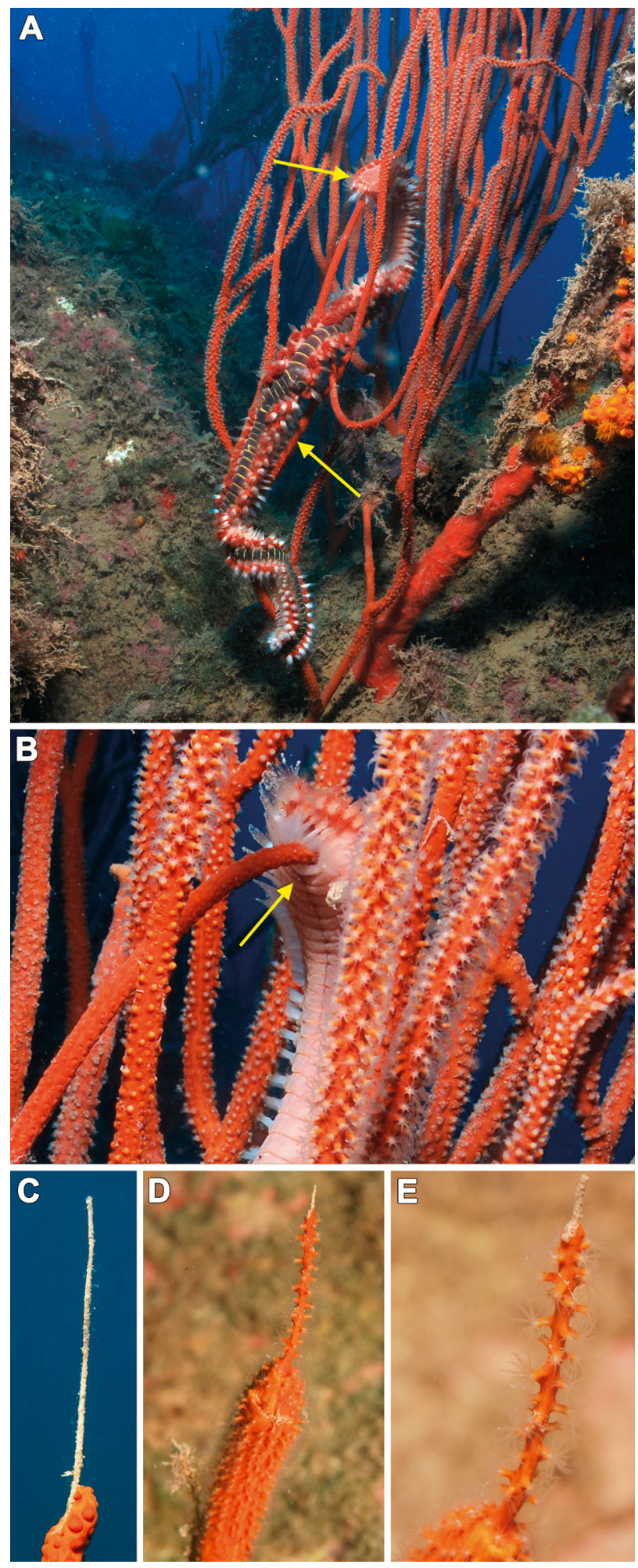

Fig. 10. Ellisella paraplexauroides and Hermodice carunculata. Predation of the gorgonian by large individuals of the polychaete. (A) General view of a polychaete (yellow arrows) climbing a gorgonian colony. (B) Detail of the worm's proboscis (yellow arrow) while ingesting the tip of a gorgonian branch. (C) A branch tip after predation by the polychaete. $(D, E)$ Details of previously depredated tips that have (D) regenerated the coenosarc and (E) produced new polyps
Smaller species, such Eunicella spp., often reach much higher colony densities (Table 1). Populations of midsized gorgonians, such as Paramuricea clavata (Risso, 1826) and Leptogorgia sarmentosa (Esper, 1791) show more modest density values, but these are still high in comparison with E. paraplexauroides (Table 1). Better comparative data might be obtained from gorgonian corals of large size (i.e. $>50 \mathrm{~cm}$ in mean height; Table 1), such as the epibathyal, Atlantic-Mediterranean Callogorgia verticillata (Pallas, 1776) and the bathyal, boreal Atlantic Paragorgia arborea (Linnaeus, 1758), which both have densities one to 3 orders of magnitude lower than those recorded for E. paraplexauroides (Table 1). In other words, E. paraplexauroides in the study area occurs at far higher densities than other large species.

Another striking feature of the Ellisella paraplexauroides population of the Chafarinas Islands is that many of the undamaged colonies are up to $167 \mathrm{~cm}$ high and exhibit notable branching complexity (up to 72 tips). Such colony 'splendor' on the shallow Chafarinas bottoms belies the belief that this species finds its most suitable or preferred habitat in the deepest areas of the continental shelf (50 to $150 \mathrm{~m}$; Arroyo et al. 2008). In the absence of a consistent correlation between any morphometric or abundance parameter and depth, it cannot be assumed that the Chafarinas population consists mainly of highly stressed colonies living at the upper limit of their bathymetric tolerance range. Our ROV inspection of the Alboran Island deep shelf (70 to 200 m; Fig. S1 in the Supplement at www.int-res.com/articles/suppl/ m479p127_supp.pdf) revealed rocky outcrops and boulder bottoms covered by dense populations of the large, unbranched gorgonian Viminella flagellum (Johnson, 1863), with only scattered colonies of $E$. paraplexauroides (Fig. S1A,B in the Supplement). All in all, one cannot discount the possibility that E. paraplexauroides is eurybathic rather than a deep-water species. Its fragmentary distribution in Mediterranean shallow habitats may have a paleozoogeographic explanation. Since this gorgonian appears to be more abundant in the Mauritanian and Macaronesian regions of the Atlantic, it may have entered the western Mediterranean as part of the documented interglacial faunal invasions during the Pleistocene, when the distribution area of numerous Senegalian and Mauritanian marine species may have expanded into the western Mediterranean. While some of those species became established and proliferated in the Mediterranean, others regressed during subsequent glacial periods, with some now persisting as mere vestigial relics (e.g. Zeuner 1959, 
Table 1. Comparative summary of average and maximum density (data pooled from assorted studies) for small-medium (mean height $<50 \mathrm{~cm}$ ) and large (mean height $>50 \mathrm{~cm}$ ) gorgonians common in the Mediterranean and/or the North Atlantic. Mean and maximum sizes for each species come from the specific populations reported in the studies cited in the Source column. $1=$ Linares et al. (2008); $2=$ Gori et al. (2011); $3=$ Weinberg (1976); $4=$ Weinberg (1979); $5=$ Rossi et al. $(2011) ; 6=$ Coma et al. (1994); 7 = Coma et al. (1995); 8 = Linares et al. (2005); 9 = Sánchez et al. (2009); $10=$ Mortensen \& Buhl-Mortensen (2004)

\begin{tabular}{|c|c|c|c|c|c|c|}
\hline Species & $\begin{array}{l}\text { Mean/max } \\
\text { size }(\mathrm{cm})\end{array}$ & Depth (m) & Study area & $\begin{array}{l}\text { Density } \\
\left(\text { colonies } \mathrm{m}^{-2} \text { ) }\right.\end{array}$ & $\begin{array}{l}\text { Max density } \\
\left(\text { colonies } \mathrm{m}^{-2} \text { ) }\right.\end{array}$ & Source \\
\hline Eunicella singularis & $16 / 67$ & $0-50$ & W Mediterranean & 33 & 38.31 & $1-4$ \\
\hline Leptogorgia sarmentosa & $26 / 34-94$ & $0-70$ & W Mediterranean & 1.2 & 10.17 & $2-5$ \\
\hline Paramuricea clavata & $24 / 98$ & $0-70$ & W Mediterranean & 20 & 44.34 & $1-4,6-8$ \\
\hline Callogorgia verticillata & $76 / 122$ & $546-570$ & Cantabrian Sea & 0.008 & 0.22 & 9 \\
\hline Paragorgia arborea & $57 / 180$ & $183-498$ & Boreal Atlantic & 0.006 & 0.006 & 10 \\
\hline Ellisella paraplexauroides & $76 / 167$ & $12-32$ & Chafarinas Islands & 0.59 & 5 & This study \\
\hline
\end{tabular}

Fairbridge 1961, Maldonado \& Uriz 1995). That would explain the rarity of E. paraplexauroides across the western Mediterranean and its extremely fragmented distribution (Fig. 1). In view of its sparse occurrence in the Mediterranean and vulnerability to demographic collapse, E. paraplexauroides may be a good candidate for a conservation plan.

\section{Size distribution and allometry}

Maximum colony height reported for this species falls in the range of 1 to $2 \mathrm{~m}$ (Stiasny 1936a,b, Hofrichter 2005, Templado et al. 2006, Angiolillo et al. 2012), which coincides with the maximum height of $1.67 \mathrm{~m}$ recorded in the quadrats of the current study. Unlike other gorgonians, Ellisella paraplexauroides does not display branch development preferentially constrained into a single plane. Most of the colonies we examined had 5 to 15 terminal branches, although some had as many as 72 (Fig. 5C). This branching pattern accords with that widely reported in the literature for this species (e.g. Stiasny 1936a, Angiolillo et al. 2012), except in colonies off the Canary Islands, which typically display no more than 5 branches (Brito \& Ocaña 2004). We found no noticeable morphological differences between the sclerites in the colonies of the Chafarinas population (data not shown) and those reported for colonies from Mauritania (Stiasny 1936a,b), the Canary Islands (Brito \& Ocaña 2004), and the Strait of Sicily (Angiolillo et al. 2012). In view of the branching peculiarities and unusually deep distribution of colonies off the Canary Islands, molecular tools would help to confirm that the Mauritanian, Macaronesian and Mediterranean colonies are actually conspecific rather than cryptic species.

The distribution of volume classes indicates that small (and presumably young) and midsized colonies are abundant (Fig. 5A), which suggests success in recruitment in previous years (or decades, depending on the still unknown growth rate). However, very few colonies are less than $20 \mathrm{~cm}$ in height (Fig. 5B), which suggests that recruitment has not been that successful in recent years. Note, too, that the distribution of volume classes and height classes may not correspond because early growth in young colonies occurs mainly in height (reaching up to $60 \mathrm{~cm}$ ) rather than in branches or volume (or biomass). In other words, the 154 colonies in the small-volume classes are indeed distributed in about the first 6 height classes. The regression analyses exploring the relationship between colony height and volume, and between colony height and number of tips (Fig. 6) also corroborated the idea that young colonies grow more rapidly in height and that they only increase rates of branch production and thickening once a threshold height (60 to $100 \mathrm{~cm}$ ) has been reached. Consequently, as more accurately indicated by height distribution data, actual recruitment can be considered low to moderate in this population. How these morphometric parameters relate to age and sexual maturity remains to be investigated.

\section{Damage, mortality and conservation}

During our 3 year study, we saw no sign of disease in the Ellisella paraplexauroides population of the Chafarinas Islands. However, branch tips were being preyed upon by huge $(0.5 \mathrm{~m}$ long on average) individuals of the polychaete Hermodice carunculata (Fig. 10A-C), although colonies appeared to recover easily, regenerating their coenosarc and polyps without difficulty (Fig. 10D,E). Likewise, marine pollution by the local human population cannot account for the substantial dam- 
age sustained by the gorgonian population, as most mortality was observed at the 2 uninhabited islands. Any irreversible damage noticed in the Chafarinas gorgonian population appears to derive from continuous unregulated fishing within the SCI area, primarily from gillnetting and trolling but also from occasional trawling. Daily unregulated use of nets and fishing lines has an adverse effect not only on the coenosarc and polyps, but also on the tridimensional architecture of the colonies (Figs. $9 \& \mathrm{~S} 1 \mathrm{C}$ in the Supplement). In many cases, tangled fishing gear and broken branches drastically disrupt the pattern of water circulation through the colony branches. Colonies disturbed in these various ways are then easily settled by larvae and propagules from a diverse array of benthic organisms. As further evidence that injury by fishing gear facilitates epibiosis in the Chafarinas population, ROV studies of the deep-water colonies (70 to $200 \mathrm{~m}$ ) on the Alboran Island shelf showed almost no epibionts (Fig. S1A,B in the Supplement). In the few cases in which epibionts were detected, we corroborated coenosarc scars adjacent to the epibiont attachment point (Fig. S1C in the Supplement). The relationship between epibiosis and mortality in the Chafarinas population and fishing activities is also supported by the fact that epibiosis and mortality are statistically higher in zones A and $\mathrm{C}$, where fishing pressure is higher than in reduced-fishing zone B. About half $(44.6 \%)$ of the colonies originally growing in zone A are currently dead, and about $82 \%$ of the surviving colonies show substantial epibiosis. Similar though less intense negative effects have been described for the population of Paramuricea clavata in the Ligurian Sea (Mediterranean), where frequent recreational line fishing has damaged 22 to $37 \%$ of colonies growing to a depth of $20-25 \mathrm{~m}$ (Bavestrello et al. 1997). Likewise, lost hook-andline fishing gear at the coral reefs of the Florida Keys National Marine Sanctuary has had a serious impact on sponges and benthic cnidarians, causing tissue abrasions that lead to partial individual or colony mortality (Chiappone et al. 2005). Branching gorgonians (Octocorallia) were the most frequently affected organisms (56\%), followed by milleporid hydrocorals $(19 \%)$ and sponges $(13 \%)$. Our finding that small-scale gillnetting by local fishermen is severely impacting the population of E. paraplexauroides is also consistent with the conclusions of another recent study assessing the impact of artisanal fishing fleets in Baja California, Mexico (Shester \& Micheli 2011), in which gillnetting reportedly damaged or removed about $17 \%$ of gorgonians within a distance of $1 \mathrm{~m}$ from the net.

In summary, unregulated local fishing activities are extremely harmful to the Chafarinas population of Ellisella paraplexauroides (Figs. 2B \& 9), while recruitment in recent years appears to have been moderate to low. The next step of research should be to determine whether recruitment is failing to compensate for the combination of natural plus fishermandriven mortality in this population and to elucidate the magnitude of the imbalance. In the meantime, if the regulation of fishing activities is not efficiently enforced within at least the SCI perimeter of the Chafarinas Islands, this unique population of E. paraplexauroides may be at high risk of rapid and dramatic decline in the short term, and annihilation in the long term. A conservation strategy giving the species protected status would ensure the preservation of this rare gorgonian in the Mediterranean Sea.

Acknowledgements. The authors thank C. Navarro, G. Martínez, M. I. Hermoso, J. Díaz, J. Zapata, M. del Sol Lizana, and the Spanish Army at the Chafarinas Islands for providing help with fieldwork and logistic support at the island station. Special thanks to J. C. Calvín for field support and contributing images (Figs. 2A \& 9A,C). S. Gofas, C. Salas, and A. Luque are also thanked for implementing the logistics for ROV exploration of the deep shelf of Alboran Island within the framework of the LIFE+ INDEMARESALBORAN EC grant, from which this study has benefited. We are also grateful for the helpful input of 4 anonymous reviewers who commented on earlier versions of this paper. Special thanks are given to V. Macintyre and K. Rützler for critical reading and language corrections on the final manuscript version. The work conducted at the Chafarinas Islands was primarily funded by an OAPN research contract, but it also logistically benefited from BFU2008-00227/BMC grant to M.M.

\section{LITERATURE CITED}

Angiolillo M, Bo M, Bavestrello G, Giusti M, Salvati E, Canese S (2012) Record of Ellisella paraplexauroides (Anthozoa: Alcyonacea: Ellisellidae) in Italian waters (Mediterranean Sea). Mar Biodiv Rec 5:e4

Arroyo MC, Barrajón A, Moreno D, López-González PJ (2008) Ellisella paraplexauroides Stiasny, 1936. In: Barea-Azcon JM, Ballesteros-Duperón E, Moreno D (eds) Libro rojo de los invertebrados de Andalucía, Book I. Consejería de Medio Ambiente, Junta de Andalucía, Sevilla

Bavestrello G, Cerrano C, Zanzi D, Cattaneo-Vietti R (1997) Damage by fishing activities to the gorgonian coral Paramuricea clavata in the Ligurian Sea. Aquat Conserv 7: 253-262

Brito A, Ocaña O (2004) Corales de las Islas Canarias. Francisco Lemus, La Laguna

Cerrano C, Bavestrello G, Bianchi CN, Cattaneo-Vietti R and others (2000) A catastrophic mass-mortality episode 
of gorgonians and other organisms in the Ligurian Sea (North-western Mediterranean), summer 1999. Ecol Lett 3:284-293

Chiappone M, Dienes H, Swanson DW, Miller SL (2005) Impacts of lost fishing gear on coral reef sessile invertebrates in the Florida Keys National Marine Sanctuary. Biol Conserv 121:221-230

Coma R, Gili JM, Zabala M, Riera T (1994) Feeding and prey capture cycles in the aposymbiontic gorgonian Paramuricea clavata. Mar Ecol Prog Ser 115:257-270

Coma R, Zabala M, Gili JM (1995) Sexual reproductive effort in the Mediterranean gorgonian Paramuricea clavata. Mar Ecol Prog Ser 117:185-192

Coma R, Ribes M, Serrano E, Jimenez E, Salat J, Pascual J (2009) Global warming-enhanced stratification and mass mortality events in the Mediterranean. Proc Natl Acad Sci USA 106:6176-6181

Fairbridge RW (1961) Eustatic changes in sea level. In: Ahrens LH (ed) Physics and chemistry of the Earth. Pergamon Press, New York, NY

Garzón-Ferreira J, Zea S (1992) A mass mortality of Gorgonia ventalina (Cnidaria, Gorgoniidae) in the Santa Marta area, Caribbean coast of Colombia. Bull Mar Sci 50:522-526

Gori A, Rossi S, Berganzo E, Pretus JL, Dale MRT, Gili JM (2011) Spatial distribution patterns of the gorgonians Eunicella singularis, Paramuricea clavata, and Leptogorgia sarmentosa (Cape of Creus, Northwestern Mediterranean Sea). Mar Biol 158:143-158

Grasshoff M (1992) Die Flachwasser-Gorgonarien von Europa und Westafrica (Cnidaria, Anthozoa). Cour Forschinst Senckenb 149:1-35

Hall-Spencer JM, Pike J, Munn CB (2007) Diseases affect cold-water corals too: Eunicella verrucosa (Cnidaria: Gorgonacea) necrosis in SW England. Dis Aquat Org 76: 87-97

Heifetz J, Stone RP, Shotwell SK (2009) Damage and disturbance to coral and sponge habitat of the Aleutian Archipelago. Mar Ecol Prog Ser 397:295-303

Hofrichter R (2005) El mar Mediterráneo. Fauna, flora, ecología, Vol I: Guía sistemática y de identificación. Ediciones Omega, Sabadell

Linares C, Coma R, Díaz D, Zabala M, Hereu B, Dantart L (2005) Immediate and delayed effects of a mass mortality event on gorgonian population dynamics and benthic community structure in the NW Mediterranean sea. Mar Ecol Prog Ser 305:127-137

> Linares C, Coma R, Garrabou J, Díaz D, Zabala M (2008) Size distribution, density and disturbance in two Mediterranean gorgonians: Paramuricea clavata and Eunicella singularis. J Appl Ecol 45:688-699

Maldonado M, Uriz JM (1995) Biotoic affinities in a transitional zone between the Atlantic and the Mediterranean: a biogeographical approach based on sponges. J Biogeogr 22:89-110

Mortensen PB, Buhl-Mortensen L (2004) Distribution of deep-water gorgonian corals in relation to benthic habitat features in the Northeast Channel (Atlantic Canada). Mar Biol 144:1223-1238

Editorial responsibility: Matthias Seaman, Oldendorf/Luhe, Germany
Nagelkerken I, Buchan K, Smith GW, Bonair K and others (1997) Widespread disease in Caribbean sea fans: II. Patterns of infection and tissue loss. Mar Ecol Prog Ser 160: 255-263

Oceana (2006) The corals of the Mediterranean. OCEANA/ Fondazione Segna, Madrid

> Ott B, Lewis JB (1972) The importance of the gastropod Coralliophila abbreviata (Lamarck) and the polychaete Hermodice carunculata (Pallas) as coral reef predators. Can J Zool 50:1651-1656

Perez T, Garrabou J, Sartoretto S, Harmelina JG, Francour P, Vacelet J (2000) Mortalité massive d'invertébrés marins: un événement sans précédent en Méditerranée nord-occidentale. CR Acad Sci Paris 323:853-865

Rosenberg E, Ben-Haim Y (2002) Microbial diseases of coral and global warming. Environ Microbiol 4:318-326

> Rossi S, Gili JM, Garrofé X (2011) Net negative growth detected in a population of Leptogorgia sarmentosa: quantifying the biomass loss in a benthic soft bottom-gravel gorgonian. Mar Biol 158:1631-1643

Sánchez F, Serrano A, Gomez-Ballesteros M (2009) Photogrammetric quantitative study of habitat and benthic communities of deep Cantabrian Sea hard grounds. Cont Shelf Res 29:1174-1188

Scinto A, Bavestrello G, Boyer M, Previati M, Cerrano C (2008) Gorgonian mortality related to a massive attack by caprellids in the Bunaken Marine Park (north Sulawesi, Indonesia). J Mar Biol Assoc UK 88:723-727

Shester GG, Micheli F (2011) Conservation challenges for small-scale fisheries: Bycatch and habitat impacts of traps and gillnets. Biol Conserv 144:1673-1681

Stiasny G (1936a) Gorgonaria von Cap Blanco (Westafrika, Mauretanien). Capita Zool 8:1-44

Stiasny G (1936b) Diagnosen einiger neuer GorgonarienArten von Cap Blanco (Westafrika). Zool Anz 113: 201-206

Templado J, Calvo M, Moreno D, Flores A and others (2006) Flora y fauna de la reserva marina y reserva de pesca de la isla de Alborán. Ministerio de Agricultura, Pesca y Alimentación. Secretaría General de Pesca Marítima, Madrid

> Tintoré J, La Violete PE, Blade I, Cruzado A (1988) A study of an intense density front in the Eastern Alboran Sea: The Almeria-Oran Front. J Phys Oceanogr 18: 1384-1397

> Vargas-Yáñez M, Plaza F, García-Lafuente J, Sarhan T, Vargas JM, Vélez-Belchi P (2002) About the seasonal variability of the Alboran Sea circulation. J Mar Syst 35: 229-248

Weinberg S (1976) Revision of the common Octocorallia of the Mediteranean circalittoral. 1. Gorgonacea. Beaufortia 24:63-104

Weinberg S (1979) The light-dependent behaviour of planula larvae of Eunicella singularis and Corallium rubrum and its implication for octocorallian ecology. Bijdr Dierkd 49:16-30

Zeuner FE (1959) The Pleistocene period: its climate, chronology, and faunal successions. Hutchinson Scientific \& Technical, London

Submitted: March 9, 2012; Accepted: November 12, 2012

Proofs received from author(s): March 5, 2013 